\title{
The Philosophical Paradigm of African Identity and Development
}

\author{
Frank Okenna Ndubuisi \\ St.Peter's Catholic Church Umunnachi, Anambra State, Nigeria \\ Email: fadaozoregbe@hotmail.com
}

Received January $7^{\text {th }}$, 2013; revised February $14^{\text {th }}$, 2013; accepted February $20^{\text {th }}, 2013$

\begin{abstract}
Identity, is the distinguishing characteristic of a person or being. African identity is "being-with" as opposed to the Western individualism, communalism as oppose to collectivism. African "self" is rooted in the family-hood. The West battered African World view and cultural heritage, with the racialism, slave trade, colonization and other Western ideologies. They considered Africans inferiors and influenced most Africans to see themselves as such. Thus Africans are backward and without integral development and independence, although it was quite certain that pre-colonial Africa was not static or dead. However, the essence of philosophy is to inquire critically into the marvels and problematic that confronts one in his world in view of producing systematic explanation and sustained response to them. Therefore, Contemporary African Philosophy focuses on these marvels and problematic confronting the Africa World. The essence of philosophical paradigm of African identity and development is to reason out the way people think with the aim of rediscovering and situating them on the right track, which is, being original and authentic with the view of arriving at a desired goal. It is also for emancipating Africa from bartered African image and European conditioning, slavery and neo-colonization. African ontology is anthropocentric; any serious minded development paradigm must take man mmadu as its point of departure and the point of arrival. It must be peoples' oriented, relevant to the peoples' needs and aspirations.
\end{abstract}

Keywords: Paradigm; Identity; Development; African Philosophy

\section{Introduction}

Africa has continuously being characterized with litanies of incommodious and incongruous conditions, such as series of famine, diverse national disasters and calamities, political instabilities, endemic tribalism, injustices, human right abuses, corruption, cultural dislocation, economic backwardness, violent conflicts, over population, mass poverty, chronic debt problems, poor and inadequate exploitation of human and natural resources. The critical rational analysis of these situations reveal straight away that the factors converged to determine the present African condition as external, which arose as a result of Africa's tragic contact with the West. The tragic experiences of racialism, slave trade, colonization and ideological contamination of Africa's post-colonial elites, have caused dislocations and some internal conditions of instability. Racialism, slave trade and colonization gave rise to African cultural alienation which also gave rise to the loss of identity and no meaningful development. However the foreignness of certain policies and development paradigms made it difficult for the people to understand, appreciate, appropriate and establish the right structures and the dispositions that would effectively operate the programme.

African philosophers and the philosophical paradigms will not set out to create a complete new African but rather seeks to know, understand, clarify, articulate and synthesize the African experience. The philosophical paradigm of African identity and development seeks and presents certain solutions that can help African rise from their racial and colonial slavery to situate the African in his world and the world at large, to foster internal and external meaningful developments.

\section{What Is African Philosophy?}

A simple definition of philosophy is not easy to come by and philosophers themselves disagree on what philosophy is or how it should be defined. It is not a dogmatic or static discipline and/or a birth-right of any race. Most professional philosophers do not agree on the nature, scope and definition of the discipline. According to J. Omoregbe, (2007: p. 1), "Plato described the philosopher as a man whose passion is to seek the truth, a man whose heart is fixed on reality". It is the quest to know and understand the reality, and certainly it begins in "wonder". In the words of B. C. Okolo, (1987: p. 31), "It was thus obvious that the early Greeks were struck by 'cosmological wonder', wonder about their daily experience of the world. They wanted to understand the truth of their experience”. Philosophy involves critical investigations, questions, analysis, synthesis and clarifications. Philosophy according to P. Iroegbu, (1994: p. 116) "is the reflective and systematic investigation into the fundamental questions that confront human being”. And B. C. Okolo (1992a: p. 30) adds, "For at the bottom, every philosophy is inseparable from peoples' world and their perception of it”.

African philosophy could be seen as essentially an activity, a project, a systematic, coherent inquiry into African experience and his world and how he conceives and interprets the universe. According to, P. Iroegbu, (1994: p. 116) "African philosophy is the reflective inquiry into the marvels and problematic that confronts one in the African world in view of producing sys- 
tematic explanation and sustained responses to them”. African philosophy should take cognizance of the African past and present experience in openness for the future through searching, critical inquiry and well-informed criticisms, not only to rediscover, discover, know and interpret his world, but also to master it and enhance it. Philosophy for G. O. Ozumba, (2003: p. 1), "are both a path-finder and a heuristic for speculating for the future and for psychologically equipping men for the challenges of the present and the future”. And for T. U. Nwala, (1985: p. 4), "the end of every true philosophy is the liberation of man from the tyrannies of nature and from the injustices in society". Little wonder B. C. Okolo, (1992a: p. 61), asserts, "the aim of all philosophizing is the truth of the universe and of African philosophy, the truth of the African and his world".

From the foregoing, one can convincingly deduce philosophy as critical reflection and investigation into the problems and marvels that confronts one in his world; which systematically and psychologically equip him to respond to them. Hence philosophy aids discoveries and development.

\section{What Is Paradigm?}

It has a wide range of interpretations and usage. A paradigm provides a conceptual framework for seeing and making sense of the social world. Paradigms influence research process and researcher. Paradigm is from the Greek term "Paradeigma""Pattern", "Example”, "Sample". It is from "para" meaning "beside", "beyond" and "deiknumi" meaning "to show, "to point out". Thomas Kuhn defined paradigm as "the underlying assumptions and intellectual structure upon which research and development in a field of inquiry is based" (http://www.paradigm). It means a certain way of thinking about something that is generally accepted. It can also mean a standard or a routine method of achieving a research. It is often referred to as the rules, examples and models our minds use to filter information. To be located in a particular paradigm is to view the world in a particular way. A paradigm is an interpretative framework, which is guided by "a set of beliefs and feelings about the world and how it should be understood and studied”,

(http://www.paradigm). For example, in social science, the term is used to describe the set of experience, beliefs and values that affect the way an individual perceives reality and responds to that perception”, (http://www.paradigm). A paradigm is a worldview, a general perceptive, a way of breaking down the complexity of the real world. It is also according to S. T. Krauss, "basic belief system or worldview that guides the investigation", (http://www.nova.edu/sss/QR/). It is a way of thinking or a system of beliefs. However, "the significance of paradigms is that they shape how we perceive the world and are reinforced by those around us, the community of practitioners", (http://www.paradigm).

There are other uses of the term "paradigm." For instance, it is used in linguistics and science in order to describe certain concepts. Paradigms are frameworks for ideas about certain subjects. Paradigm serves as pattern or model. It is a set of assumptions, concepts, values and practices that constitutes a way of viewing reality for the community that shares them, especially in an intellectual discipline.

\section{Philosophical Paradigm}

The problems of the early philosophers were the "wonders" of the universe. And the reasons for philosophizing, among other things are; the origin of the universe; the whyness of things, the reality of things, an inquiry into existence and reflection on human experience, both past and present. Human beings, have natural inclination to understand and make meaning out of their lives and experiences”, (http://www.paradigm). It has been pertinent on man to make rational and critical observations and questioning about himself and his environment. There are lots of assumptions and concepts in the quest to give good account or make understandable explanations about man and the universe. However, not all of them have been philosophically investigated. Since paradigm is a term used to describe model, standard, worldview, a set of experiences, basic belief system, or values that affect the way an individual perceives reality and responds to that perception. Also since paradigm is an interpretative framework which is guided by a set of beliefs and feelings about the world and how it should be understood and studied, it has to be critically and rationally questioned and investigated. It does seem that philosophical paradigm could be considered as philosophical assumptions, doctrines or philosophical framework.

Philosophical paradigm consists of those assumptions, concepts, basic beliefs, doctrines or assertions that have been critically and rationally investigated and evaluated. Philosophical paradigm is a rational inquiry or reflection on the basic beliefs, worldview, thoughts and assumptions of a people. In the words of Ezeani (2005: p. 12), “The end of iquism or philosophical questioning/ inquiry is to discover truth with a view to bringing about a change in belief, practice or attitude”.

\section{What Is African Identity?}

African philosophy bears on African identity. To understand this more, we have to consider or address certain questions such as: what is identity? What actually characterizes a person as an African? These questions revolve around the issue of identity.

However, for P. Iroegbu, (1994: p. 116), "by African, is understood the geo-political and socio-cultural entity englobed by the continent Africa”. Panteleon Iroegbu considers more of the place and location. But the questions above went beyond geographical location or designation, the term refers to a being or reality or one who can directly or indirectly trace his route to the African soil or having the characteristics of Africanity. What is rather important is to assert that the African is identifiable naturally. The fact remains that, the question of African identity bears on the principle of being that "what is, is and what is not, is not". It shows, that being is and non-being is not. On this, Richard H. Popkin, (1993: p. 101), says; "What is, cannot change into what is not without passing out of existence. Hence, the permanent, the real is and cannot be part of reality or become part of reality. It is what it is, and to become something other than this would involve the contradiction, that it has become what it is not”. Also according to Webster's Universal Dictionary and Thesaurus: Identity means "the distinguishing characteristics of a person and personality". The quest for identity embodies the value expressed by one of the first principles of being. This principle states that "every being is determined in itself, is one with itself and is consistent in itself”. Therefore every being is one in itself and divided from the others. That is to say that every being is separate from the others and the qualities of matter such as colour, size, and shape and so on distinguish the same being from the other. 
M. A Dukor, (2010a: p. 156), makes it clear that "the problem of identity in philosophy started in the pre-Socratics, when the early Greek philosophers tried to look for the basis and substance of the universe. In the course of this, they came to a conclusion that there must be an original primary stuff of which all things are made and also which explains the continuity in the changes and the underlying unity in the plurality of things". According to M. Dukor, (2010a: p. 158), "while human nature and dignity is universal and common to all men, each human person is also a particular mix of the entire element which goes to its making. This particular mix determines his individual personality that is his character, his temperament and individuality". He moves further to say that "man is rational and free but these typical human characteristics combine with other physiological aspects of being or human being to create an identity". And every normal human being feels the need to identify with a group of people. Indeed, human identity paves the way for personal identity. It is appropriate to know what a thing is and what can be legitimately attributed to it.

\section{What Then Is Really African Identity?}

Some scholars are of the opinion that the search for African identity is not feasible, since Africans are not one but many peoples and races with a diversity of cultural beliefs, languages and traditions. Emphasizing the truncated effects of African unhealthy contact with the West as the main cause and problem of African identity crisis; M. Dukor, (2010a: p. 160), says; "Racialism, slavery and colonialism gave rise to the African psychological and cultural alienation which also gave rise to the loss of collective identity". Also according to E. A. Ruch and K. C. Anyanwu, (1981: p. 168), "it is all this, this racialism, the slavery and the oppression of colonialism, the ambiguities of attitudes on the part of both whites and blacks which gave rise to the psychological and cultural alienation to the loss of collective identity of the Africans". The West considered Africa as inferior and without reasoning. They felt that the colour: White is superior while Black is inferior and that the blacks were condemned to be primitives. According to M. Dukor, (2010a: p. 159), "Africans of the first half of this century have begun to search for their identity because they had the feeling that they had lost it. The three factors which led to this feeling were; slavery, colonialism and racialism of all these, racialism is said to be the source of the colonialism and slavery. It was because Africans were considered racially inferior and culturally uncivilized that both Arabs and Europeans felt a moral justification in expiating them by reducing them to slavery. Therefore the heart of the whole problem of African identity lies in Racialism”.

African identity, bears on the stuff of which any African can be identified and associated with appropriately and comfortably. It bears also, on that underlying element of unity in the plurality of all African peoples. It does not subsist on the accidental facts, may be, by the virtue, that one was born and bred or lives in the African continent. This does not qualify to be an original primary stuff of the being. However M. Dukor, (2010a: p. 157), asserts certain basic primary stuffs on African identity. He considers African mind or consciousness: "that we are persons and we can think which is the major activity here". This is the fact of group consciousness, having common experience or goal. According to him, (2010a: p. 157), "we need to ask ourselves, if we have minds, we can then identify our thoughts by being conscious of our minds". The issue of rising to consciousness is very important in the philosophical inquires and search for identity; it was the solid ground for Rene Descartes philosophical enterprises. This consciousness can help to unite the many peoples and races with diversity of cultural beliefs, language and tradition in the African continent. He explains further, (2010a: p. 159), “Then people who become aware of themselves as they imagine themselves as history has made them, who treasure their own past and who love themselves as they or imagine themselves to be with a kind of inevitable introversion. Hence identity is a function of culture, group and collective personality”. In this case, (p. 157), "We take identity as something that is both physical and transcendental”.

Colour is another element of identification: Black is one of fundamental elements of African identity. According to him, (2010a: p. 157), “There is a particular continent where we have large concentration of black people, and that the continent is called Africa. Therefore any man that has a black colour is called an African”. This suggests the appreciation of a colour as an identity. Most of African traditional nationalists emphasized and appreciated the African treasured colour; Black. African continent is known as the land of the black and African race is a black race. It qualifies to be an original primary identity, the blackness and other important features. On another note, M. Dukor, (2010a: p. 157), explored the generosity and hospitality of African people thus, "looking at the ethical dimension, it has been established for example that the Africans generally welcome people into their community even when they see that you are a stranger, they still welcome you well. But in many other parts of the world it is not like that".

African identity centers first and foremost on the African self-hood. It is important and proper to assert that the African is easily identifiable ontologically. In African metaphysics, the self is conceived essentially towards other, that is, a "beingwith-others". The African is not just a human being but essentially a "being-with". Consequently it is the community which makes the individuals, because of his relationship with other in the community. The African self is defined in terms of "Weexistence." Furthermore Julius Nyerere calls this distinctive African trait simply "African brotherhood" with its root in the African extended family system. It is discovered in African metaphysics that "the self" is conceived essentially towards others, that is a "being-with-others". Life for the African personality is an integrated network of artistically harmonious daily rhythm. In its ontological relationships, the self in African metaphysics is attained to both the visible and invisible worlds. In his words, Placid Temples, (1959: p. 60), says in Africa we: “... cannot conceive of man as an individual as a force existing by itself and apart from its ontological relationship with other living beings and from its connection with animate or inanimate forces around”. Also according to Panteleon Iroegbu, (1995: p. 79) "the starting point of the definition of personality, is not the individual atomic or autonomous self, but the social, communal and relational self".

According to M. Dukor, (2010b: p. 22). "The theory of communalism is clearly applicable to different groups and norms of traditional African societies". The concept of "being-with" is in fact the fundamental idea or explanation of African identity. It is the community which makes the individuals, that is the African self is defined in terms of "WE". It is an ontological relationship. The discovery of African identity is pertinent for a holistic emancipation of African. It is for the African thinkers to assert authoritatively their unique personality in the world 
and to find self knowledge from within and not outside their culture.

\section{What Is Development?}

Change is a paramount essence of life. Development involves a certain amount of change, a change that has direction. Development is a process or activity of actualization of potentials and it involves self-thought, decision and involvement. It is an indisputable and indispensible fact of life. The word "development" is derived from the French word "veloper"meaning to "wrap". To develop means to "de-wrap", that is, to unfold gradually, to cause to grow gradually stronger and better. According to Panteleon Iroegbu, (1994: p. 81), "generally development is the progressive unfolding of the inner potentialities of a given reality. It is to develop, that is, to bring out to light existential function epistemic, what was enveloped, folded or hidden. As it implies to people's development is the integration of the various givens, natural, physical, acquired and human, of a people towards the full working out permanently and cumulatively of their being as persons of their community and of their real productivity".

Development is the fulfillment and actualization of the potentials of both natural endowments and human person. It is multi-dimensional. In the words of Walter Rodney, (1990: p. 9), "Development of human society is a many-sided process. At that of individual, implies increased skill and capacity, greater freedom creativity, self-discipline, responsibility and material well-being ... However what is disputable is that the achievement of any of those aspects of personal development is very much tied with the state of the society as a whole”. Also according to Oxford Dictionary of politics-“development is a multi-dimensional process that normally connotes change from a less to a more desirable state. It is normative concept and there is no simple accepted definition". Development is a process or an activity of actualization of potentials. It is an action of being capable through self-involvement, thought and decision. It is natural and universal, subjective and objective phenomena. This is because man and his environment have been endowed with natural potentials. And the adequate process and actions for the actualization of these potentials give rise to development.

In man, development is the ability to appropriate, analyze, understand, manage, control and appropriate his environment and cultural heritage. It involves; physical, emotional, intellectual, moral and spiritual development. However, good moral/ spiritual life is a pre-requisite for any meaningful and genuine development. On this, J. Omoregbe, (2007: p. 197), says: “A very important aspect of the development of human personality is moral development ... Moral development in the part of the citizens is therefore a condition-sine-qua-non for development through modern technology". It is indubitable that development as a process or activity is not a birthright or prerogative of any people, race or nation. This is because everywhere and in every nation, man is faced with the task of survival to meet up with the fundamental material and spiritual needs. For F. Nitsche, "life involves an uninterrupted becoming". Development can be subjective or objective, for it is a process of actualization and improvement of human nature and welfare in pursuit of perceived end of man, which is determined by the people's ideology. An integral development should permeate all the fabrics of human and national lives which include: moral, economic, so- cial, political, cultural and technological development. But in all these, development must be pro-life; that is, it must enhance life, promote life, protect life, increase and prolong life. It must be individuals or person's oriented as the case may be.

\section{The Essence of Philosophical Paradigm of African Identity and Development}

Africa's truncated slave trade, racialism and colonial experiences shook the foundations of the traditional conceptual paradigms, institutions and worldviews. And having passed through these cultural dislocations, it calls for a critical inquiry from which we can discern fundamental elements vital for development. The African now wishes to concretize his social, political, religious, economic and cultural ideas as an independent free and mature human being. He wishes to be the master of his world with its burden and joy to count and be counted in the family of nations.

Here philosophical paradigm of African identity and development tries to bring out the way the people think with the aim of rediscovering and situating them on the right track that is being original and authentic with the view of arriving at a desired goal. "It is critical inquiry done on the concepts and manner of African identity and development, believing/hoping to find what would be the basis and solution to African identity crises and meaningful development. It makes rational inquires and reflections on the thoughts, basic beliefs and practices of the people. In the words of M. Dukor, (2010b: p. 162), "the first condition for black renaissance in the knowledge of the fact there is the African problem of economic backwardness, political instability, technological inertia and total dependence on and unfreedom from the West. The problem is the knowledge that Africans lack the political will and freedom to determine their destiny in the scheme of things in the comity of nations”.

It is objectively clear that African problems of persistent identity crisis and no meaningful development have serious link with bartered and truncated effects colonialism and neo colonialism. He explains further, (2010b: p. 168), "Since the down of political freedom from colonial rule African societies have been disorganized. The assimilated Western civilization impinge negatively on the society". Colonization came with it destruction and distortion of African value systems and worldviews thus, in the words of Ezeani E. (2005: p. 45) "it is a pathological distortion of the mind; a mental state in which a person unconsciously despises what is his or hers and who he or she is, and thus instead, an inordinate love or irrepressible desire to be the other person-the colonized". It is a deranged mental state caused by colonialism. Colonization inherently disrupted and destroyed the traditional identities and distorted the notion of what we in the African continent perceived ourselves to be. According to Claude Ake, (2000: p. 16), “colonialism in Africa was markedly different from the colonial experience of the Americans, Europe and Asia”. It distorted the psyche of the African man. It brought the unconscious reflection of who or what one is or what one has. M. Dukor, (2010b: p. 165), says "This singular seed of underdevelopment has always been in form of European and US noe-colonial polices on Africa which have tended to impoverish the Africans and worsen their conditions". It therefore became imperative to fashion out a holistic approach in response to this African condition.

Philosophy seeks to influence the thinking, behavior and worldview of the people. The revival of a true African identity 


\section{F. O. NDUBUISI}

and development depend on the restoration of values as the beacon of light. He maintains (2010b: p. 168) "African world present a glaring and absurd example of the world where there are intellectual bondages and dishonesty where individuals are conceptually and circumstantially coerced into states of intellectual solitude, scientific solipsism and cave like type of existence." Thus Socrates advices "man know yourself”. Also Rene Descartes affirms "I think, therefore I am" (corgito ego sum). Also B. C. Okolo, (1987: p. 37). "There is indeed an obligation on the part of the African to know himself as Socrates commanded and to know the environment in which he lives. Through this knowledge, the African attains the truth about all reality". The question or inquiry on identity is an ardent desire to regain in Jean Paul Sartre's phrase, man's "existential integrity" which is "the original purity of his existence". This is not just for social progress, economic consolidation, but also for self-knowledge, discovery, self-actualization, qualitative and holistic development through the endowed resources of his being, culture and world. The search for identity is a mission back to the root, to become fully conscious of himself as an African.

African identity is found in African traditional worldview. For the African existence is relational. This ontological relational existence of man does not stop at relationship with the fellow humans, but embraces other physical and spiritual realities. In the words of Metuh I. E. (1990: p. 165), "Man ontologically is best viewed as a "life force" in active communion with other living forces in the world. Each person, in a nexus of interacting elements of the self and of the world which determines and is determined by his behavior". Also for Richard B. H. (2002: p. 61), “the notion of 'person hood' or 'being a person' is dependent upon people's relationship with their community”. In African traditional worldview identity is rooted in the family and the community.

In African traditional worldview, life or existence is not an individual venture, "the meaning of an individual's life is found in and through his relationship with the other or others”. Man finds meaning in the idea and reality of the other. And without others he loses his values. In the words of P. Iroegbu, (1995: p. 349), "The umunna constitutes the fulcrum of interpersonal relationships. From it the individual draws his life-forces”. In Africa man is thought as humankind in its real and substantial unity. According to T. Okere, (1996: p. 159), "The self as far studied remains in a way only an abstraction ... in fact the self is never alone. The individual is never a pure isolated individual”. For Africans, no one can be his very self outside the relation with the others and the meaning of life depends on the relationship with others.

In traditional African worldview, the metaphysical search for why "I" exist should coincide and link with the search of why "we" live. And on this B. C. Okolo, (1992a: p. 64), writes "man is a being in process and his experiences grow along with him". Man therefore is held in a web-like relations and interactions with his community and other realities. In Africa one cannot think, consider any person without due reference to his family and community. They are indispensible to one another. The idea of personhood in African thought is a concept for community building. According to P. Okonkwo, (2005: p. 122), “with the implication that as the individual partakers in this corporate existence and as a member, his fortune and misfortune becomes that of the society. It is on this basis that any grave violation of the moral order has serious social consequence. It is not only the individual offender but the whole community becomes polluted by such act. So the idea of corporate responsibility is therefore very strong in Igbo (African) traditional set up”. However, for Temples P. (1959: p. 105), "you cannot conceive of man as an individual force existing by itself and apart from its ontological relationship with other living beings”. Then in the words of Egbeke Aja, (2001: p. 58), "the ontological order in interaction is that whatever happens to the individual, happens to the whole group and whatever happens to the whole group, happens to the individual”.

It is clear that African composition of reality is different from that of the Western composition. And African ontology centers on "vital force". Thus without attempting to decide this precise point, we may state emphatically that the traditional African conception of the world is one in which life force plays an essential part. African ontology holds two structures of the world: the cosmological and metaphysical African communities recognize the plurality of worlds; visible and invisible the physical and the spirit world. The two worlds interact as there is no clear-cut distinction between the Spiritual and the physical. Reality is homogeneous in the African worldview.

This is because everywhere and in every nation, man is faced with the task of survival, to meet up with the fundamental material and spiritual needs. For F. Nitsche "life involves uninterrupted becoming”. Development can be subjective and objective for it is a process of actualization and improvement of human nature and welfare in pursuit of perceived end or goal of man, which most often is determined by the people's ideology. According to M. Dukor, (2010a: p. 159), “in talking about development, one must bear in mind that the concept is a holistic concept which manifest the cultural, the political, the social and the scientific". Also every society has its own share of natural material and human resources for better life, better society and world.

Development has been constant in a varying degree within human societies, since the origin of man. For man has multiplied enormously his capacity to wind living from nature and dial with the numerous challenges and tasks of survival. However different areas where development is needed include economy, politics, social, moral, culture, technology and most importantly and especially as every other form of development is directed towards it is the human development. It appears that the concept development was adopted while referring to the nations was seen as a destination that could be reached. And the so-called developed nations have reached it while the undeveloped nations of Africa are still very far away from the destination. Invariably what this implies is that the developed nations have reached the apex of human and national potentials while the others still have long way to g o. After analyzing the implication of this conception of development, Joseph Desire (the eccentric Mobutu Sese Seko) of Zaire in his address to the united Nations General Assembly in 1976 argues thus, Chumbow B. S. (2005: p. 166) "all countries are in a state of perpetual development and as such no country not even the most development and as such no countries of Europe and America, has stopped developing; therefore they also logically qualify as developing countries.”

Mobutu submission has two implications. First: development is no terminus ad quem, otherwise the so-called developed nations ought to pack up their bags of inventions and stop the massive investment they make. Then secondly, it is a misconception to label some countries as undeveloped since every 
country in a sense is developing. Development is a continuous and gradual process or activity no matter how minute it may appear. Even certain developments do occur in death, that is evident in a situation where being or reality metamorphosed or transformed into a more perfect being or reality of the same specie and substance, but there must be an ontological or fundamental links or connections. It is quite certain that pre-colonial Africa was not static or dead. Although the West mistakenly thought as much for they believed that Africans had no soul and intellect or reasoning. The pre-colonial Africans were at that time, building their houses, farming, making tools and utensils for various purposes, finding medicines and devising certain systems of agriculture and trapping animals. There were among them-cultivators, sculptors fishermen, trade societies, raiders and nomads. They were progressive and drawn into certain contacts and relationship with each other and with tribes and towns. There were also some levels of expansions of productive forces and network of distributions. On this note, Toyin F. (2000: p. 16), writes, Thus "long distance trade within Africa and Nigeria in particular was very active in pre-colonial time. In fact with the decline of the major empires, the trans-Sahara trade routes shifted to Kano and Kaduna in 19th century". Also according to Walter Rodney (1990: p. 21), "Africa and Asia societies were developing independently until they were taken directly or indirectly by the capitalist's powers". Development is never a new concept or bequeathed phenomena from the west. For G. Olusanya (1998: p. 9), rightly observed that "prior to the arrival of the British, the various formations that made up the pre-colonial Nigeria (Africa) had already developed a fairly advanced level of economic interactions among themselves especially in the area of trade". Development is obviously inherent in all human societies for man is a bundle of possibilities and potentialities. However, Africa traditional or pre-colonial societies were characterized by mutual help and communalism and which were dislodged as a result of slave trade and colonial influences.

The West packaged their experience as the basic, ideal, model, standard, universal, objective and conditio-sinequa non for Africa good and development. However their development paradigm have a negative view or false knowledge of the people and their worldview. And as such, its point of departure from the onset is false, that is not what is, but what they thought ought to be. In other words, people were going somewhere without being quite sure of the directions, this has resulted in political instability, religious, economic crises and lots of other crises and unrests. Development and its paradigm ought not be superficial rather it should be deep rooted and a holistic enterprise. It should not be foreign or imposed but rather, original, self-evolving and people oriented. Most of their policies were essential aimed at the discouragement and sometimes destruction of local initiatives.

The foreignness of the policies and development paradigms made it difficult for the people to understand, appreciate, appropriate and establish the right structures that would effectively operate the program. And as it were, the post-colonial elites seemed to have been caught in the web of false sense of development and struggle for power and wealth. There was the problem of moral relativism and consequent growth of ethnic protectionism and religious intolerance. However from the foregoing, one can observe and clarify certain facts in the first instance; development is not the birth-right or prerogative of any people, group, race or tribe, it is a natural inherent reality.
The West has not the monopoly or the last word on it. It is peoples' oriented. It carries the people, their environment, needs and worldview along. At the same time, development does not negate a proper or balanced cross-pollination of ideas and values. In the words of M. Dukor, (2010b: p. 157), "any concept of development that negates the African prototype or the Asian, is automatically out of the global process".

Generally African situation is not a palatable one. When you consider the happenings around Africa, what stare you, are series of in the words of Chumbow B. S. (2005: p. 166), "famine and diverse natural disasters and calamities, instability of political regimes ... poor or inadequate exploitation of natural and human resources". And also for Ake C. (1998: p. 52), "the chronic debt problems, the declining productivity and negative growth rates and the threat of starvation to over 150 million people on the continent”. However consequent upon these, the philosophical paradigm for African identity and meaningful development has to do with the people's needs through the re-orientation of the African traditional worldview. According to Emmanuel Ome, (2007: p. 141), “Any development effort that is not relevant to peoples' needs and aspiration is misplaced and automatically losses its name and character". Philosophy equips man with the right intellectual capacities, for it involves critical investigations, questions, analysis, synthesis and clarifications. The African philosophers and philosophical paradigms set out to understand, clarify, articulate and synthesize the African experiences. These experiences could be categorized in the words of B. C Okolo, (1992b: p. 17), as "cosmological wonder” and "ontological wonder”. For him, "what the early Greeks experienced as the root-origin of their philosophic inquiries was therefore "cosmological wonder". Then African nations realized that through "cosmological wonder" that their world, their mode of being in the world was untrue and inauthentic thus: the "cosmological wonders" shifted on to "ontological wonder" when the African realized also that his very being was affected also he was conceived as below human”. And according to G. O. Idjakpo (2002: p. 153), “Ontological problem also concerns the relation which exists between reality and human beings on one hand and the soul on the other”.

Most early philosophers had established the relevance of philosophy and philosophers to nation building, integral human and natural developments whish Socrates emphasized the value of trained intelligence, wisdom and prudence for a country's leader. Plato holds the importance of philosophy and philosopher king in the building and substance of a stable polity. On this Ome E. (2007: p. 141), "Philosophy in Africa and Nigeria in particular should seek answers to the turbulent development problems, the lack of progress in Africa and the black race, backwardness in education, endemic tribalism, injustice, corruption, human right abuses, political disequilibrium and marginalization, cultural and economic powerless, violent, conflicts over population and mass poverty etc.”. Also for B. C. Okolo, (1992b: p. 17), "Philosophy lives by constant criticisms but its questioning and criticism, whether of beliefs or concepts are ultimately to influence the lives of men in the society such that life without criticism is not worth living. In other words that nature of philosophic task is practical rather than theoretical”. Philosophy and philosopher influence human and national development. For instance, Socrates was a gadfly, arousing the state from their "dogmatic slumber", self-consciousness, selfcriticism, evaluation and development. It is pertinent task of 
African philosophers to reflect the ways philosophy can help Africa to rise from their colonial and slavery prison, situate the African in his world, foster internal and external developments. Africa's true development will be possible with proper reorientation on African identity value system and worldview. According to P. Iroegbu, (1994: p. 116), "In developing various aspects of reality, the human being develops himself. In developing himself he passes through the development of different other beings, situation and relationships. There is a crossbreeding of self-development, other development and world (material) development. One can only be neglected at the price of truncating the others".

Because of the anthropocentric nature of African worldview, any proper development paradigm should take man (mmadu) as its point of departure and the point of arrival. It must be relevant to the people's needs and aspirations. It must be African or people oriented. In the words K. Nwoye, (2000: p. 41), "Development therefore involves realizing human energy and capacities and providing opportunities for people to make the maximum contribution to their own development and to the self-sustaining development of their societies". There should be constant reorientation on the authentic African needs and value systems to the Youth, Leaders Thought, Politicians and Administrators. According to B. C. Okolo, (1992b: p. 29), "it is the distinctive role of philosophers to stimulate peoples' appetites and derives for higher ends and values in life such as true patriotism, honesty etc." It is the task of philosophers and scholars to interrupt the world and man's experience and influence him to change and transform the human societies for better.

The main tasks of the philosophical paradigm of the African identity and development are among other things to reflect on the various ways African philosophy and philosophers, can help to identify the African, situate him in his world, enhance his emancipation from mental, economic, political, neo-colonial and cultural slavery through integral peoples' oriented development. It is embarking not only upon self discovery but self recovery as well for the purpose of achieving through human dignity and independent personality in the Hegelian sense of independent self-consciousness considering the antecedents and decimal of the African identity crisis and no meaningful development, it is up to African scholars to think out the best way to comfort the situation and this is unassuming task of contemporary African thinkers to assert authentically the African unique personality in the world by re-discovering self from within and not from outside their culture. They have to articulate the convincing philosophical insight and establish the parameter within which the African can evaluate himself to the profound thinking of his essential problems. B. C, Okolo, (1992a: p. 50), comments "the African has consequently realized that it is only by developing a different orientation and method in philosophy can his needs, values, total experience and trust about is world be adequately reflected in philosophy". And in the word of T. U. Nwala, (1985: p. 4), "philosophical ideas do not emerge from the blue. They have their base in the totality of the natural and social environment. They arise in the course of man's attempt to act upon nature for purpose of sustaining his existence”. African philosophy should take cognizance of the African past and present experience in openness for the future through critical inquiry and well informed criticism not only to rediscover, know and interpret his world, but also to make it and enhance it.
In all these, development must be prolife, it must create life, enhance life, promotes life, protects life, save life, increase life and prolong life.

\section{Evaluation and Conclusion}

Generally, the African conditions have been serious worries to African nationalists, philosophers and administrators. The cultural dislocations, pathological distortion of the mind and the devastating effects of racialism, slave trade and colonization cannot be over emphasized, it has been cancerous and proving irredeemable. Well the obvious fact remains that the factors are mostly external and not ontological. Therefore the African needs an inner proper articulation coming from his ontological reality. African philosophy is the more profitable for this unique exercise. It is the main task of contemporary African philosophy.

Uroh Chris, (1998: p. 2), observes "the hopelessness of African conditions thus: African alone parades 32 of the worlds 47 least developed nations. This is often betrayed by the fact that on the average, 1000 children are killed daily in the continent by some curable diseases such as dysentery, diarrhea, cholera and what have you ... added to the above is the mounting debt bill...”. Racialism this is unholy understanding of West (while) to be superior to the Africa (black), racial superiority there by making the African an object instead of a subject of his environment. M. Dukor, (2010b: p. 139), observes "Freewill international relations and mutual co-existence of mankind therefore seems to be non-existence directly, because civilization and progress of mankind is a natural process and secondly in the interlocking Egos of races and nations, some wills of nations and races will superimpose on the will of others". David Hume one of the serious advocates of racialism holds that blacks are naturally inferior. And inferior race is assumed to be incapable of great achievement. And for M. Dukor, (2010b: p. 159), “it was because Africans were considered racially inferior and culturally uncivilized that both Arabs and Europeans felt a moral justification in exploit ting them by reducing them to slavery".

Slave trade has its woos on African developmental dislocations. The number of able-bodied young male and female that were sold into slavery remain unknown. And the consequence of this is still visible all over Africa. Slave traders preferred their victims from the ages of 15 to 35-these were mostly in child bearing age bracket and generally productive ages-the active labour force of the continent. Their shipment abroad meant a massive loss to agriculture and all other economic sectors, on this Oguejiofor, (2001: p. 30), observes "the importance of strong and balanced population in economic development cannot be overestimated. It is the mainstay of productive labour; it provides market for what is produced and by exerting social pressure on many fronts, leads to more economic advancement and general inventiveness". Slave trade as it were led to a lot of socio-cultural dislocation in Africa. It also contributed to human right abuses prevalent in the continent now. Slave trade dehumanized the human person.

Colonization came with its destruction and distortion of African psyche, traditional identities, value system and worldviews thus it opened another phase in the disorganization of African economy in order to suit the economic interest of the colonial powers. Where the Africans protested, force was used on them for colonial economic interest. Bertrand Russell, (1934: 
p. 453), provides an insight into how the Congolese were made to work for their Belgian masters: "Each village was ordered by the authority to collect and bring in a certain amount of rubber as much as the men could bring in by neglecting all work for their own maintenance. If they failed to bring the required amount, their women were taken away and kept as hostages ... if this method failed, native troops were sent into the village to spread terror, if necessary by failing some of the men". The concept of "brain drain" is another malignant cancer plaguing the African continent. This is event of continuing loss of citizens of high intelligence and creativity through emigration. According to M. Dukor, (2010a: p. 179), "The phenomenon of brain drain has eaten away the man power and intellectual resources that would have been the bedrock and galvanizing motif for African citizenship and freedom from the international capitalist system controlled from Europe".

However, African people and their leaders have been professing solutions and frameworks for the African condition, take for instance among other serious though over programmes, in July 2001, the OAU Assembly of Heads of State and Government meeting in Lusaka, Zambia, adopted this document under the name of the New African initiative $\{\mathrm{NAI}$. After all said and done, the Heads of State and Government implementation committee \{HSGIC\} for the project finalized the policy framework and named it the New Partnership for Africa's Development on 23rd October 2001. NEPAD is now a programme of the African union $\{\mathrm{AU}\}$. Its four primary objectives are to eradicate poverty, promote sustainable growth and development, integrate Africa in the world economy and accelerate the empowerment of women. It is based on underlying principles of a commitment to good governance, democracy, human rights and conflict resolutions and the recognition that maintenance of these standards is fundamental to the creation of an environment conducive to investment and long-term economic growth. NEPAD has some partners in progress such as UN Economic Commission for Africa \{UNECA\}, African Development Bank, Development Bank of Southern Africa \{DBSA\}, Investment Climate Facility $\{\mathrm{ICF}\}$, Africa Capacity Building Foundation, the Industrial Development Corporation \{IDC\}. Inspite of all these, African condition remain Bezier and non-acceptable. These programmes probably were not properly articulated. According to M. Dukor, (2010b: p. 168), "the African world presents a glaring and absurd example of a world where there are intellectual bondage and dishonestly where individuals are conceptually and circumstantially coerced into states of intellectual solitude, scientific solipsism and cave like type existence". Also for M. Dukor, (2010b: p. 164), "The problem is the knowledge that Africans lack the political will and freedom to determine their destiny in the scheme of things in the comity of nations".

However, African problem is better handled by the Africans. The African needs to rediscover himself from within and not outside his culture. Better tomorrow ought not to be seen as an automatic product or wait-and-take but the effects of solid resolutions and concretized efforts, overcoming the fears that hold us in bondage and overturning the myths of inferiority which racialism, slave trade and colonialism have placed on our heads. The African must be awake to the realities of his life, ask critical questions that concerns him, seek true answers to those questions. The first and foremost question bears on his ontological identity, so as to rediscover himself so as to assert himself authoritatively. According to M. Dukor, (2010a: p. 160), "the liberation from foreign identity and the regaining of African identity can only be done by African themselves. Only Africans can save themselves".

The rediscovery of African identity is pertinent for a holistic emancipation of Africa. African ontology is anthropocentric in nature. The self is a "being-with". The African self is defined in terms of "We-existence". And in its ontological relationships, self-in African metaphysics is attained to both the invisible and visible worlds. Having rediscovered his ontological identity it became imperative to the African to fashion out a holistic approach in response to the African traditional ontology.

In this task, African philosophy is indispensible. It takes cognizance of the African past and present experience in openness for the future through critical searching, critical inquiry and well-informed criticisms, not only to rediscover, discover, know and interpret his world, but also to master it and develop it. Philosophy and philosophers influence human and natural development. Therefore through the philosophical paradigm of African identity and development, then African can rise from the colonial and slavery experience, discover himself in his world, situate himself in his world and the world at large and achieve meaningful development. The philosophical paradigm of African identity and development seeks to enhance the emancipation of the African from mental, economic, political, neo-colonial and cultural slavery through genuine people's oriented development structures. We discovered that development is a natural process; it has been constant in varying degrees within human societies since the origin of man. Development is not a birthright or exclusive of any people or race or tribe. It is quite certain that pre-colonial Africa was not static or dead. Development is an indispensible and indisputable fact of life. It is a process or activity of actualization of potentials and it involves self-thought, decision and involvement. Development is a natural process because everywhere and in every nation, man is faced with the task of survival to meet up with the fundamental material and spiritual needs. Development must be people oriented which is in line with African ontology. It must be pro-life, that it must enhance life, promote life, protect life and increase life. It must be a corporate task to be inculcated through constant reorientations of the youth, leaders of thought, politicians and administrators.

\section{REFERENCES}

Ake, C. (1989). The political economy of crises and publishers, underdevelopment. In C. Ake (Ed.), Africa selected works (p. 52). Lagos: Julius Ihonvhere, JAD Press.

Ake, C. (2000). Democracy and development in Africa (p. 16). Ibadan: Spectrum Books.

Chumbow, B. S. (2005). The language question and national development in Africa. In T. Mkaindawire (Ed.), African intellectuals: Rethinking politics, language, gender and development (p. 166). Dakar: CODESRIA.

Dukor, M. (2010a). African freedom of philosophy (pp. 155-180). Germany: LAP LAMBERT Publications.

Dukor, M. (2010b). African philosophy in the global village; theistic panpsychic rationality, axiology and science (pp. 22,139-168). Germany: LAP LAMBERT Publications.

Egbeke, A. (2001). Metaphysics: Introduction (p. 164). Enugu: Donze Press.

Ezeani, E. (2005). Philosophy as intelligent and pragmatic questioning (pp. 12,45). London: VERITAS Lumen Publication.

Idjako, G. O. (2002). The meaning of African and Western metaphysics: A conceptual analysis. In F. A. Udiugwomen (Ed.), Footmark on African philosophy (p. 153). Lagos: Obiorah and Ogbunka Press. 


\section{F. O. NDUBUISI}

Iroegbu, P. (1994). Enwisdomization and African philosophy (pp. 81, 116,155). Owerri: International University Press.

Iroegbu, P. (1995). Metaphysics the Kpim of philosophy (pp. 79,349). Owerri: International University Press.

Metuh, I. E. (1990). Nigeria cultural heritage (p. 165). Jos: Imico Publication.

Nwala, T. U. (1985). Igbo philosophy (p. 4). Lagos: Literaned Publications.

Nwoye, K. (2000). Corruption, leadership and the dialectics of development in Africa. An exploratory perspective (p. 41). Enugu: Associated Press and Litlo.

Oguejiofor, J. O. (2001). Philosophy and the African predicament (p. 30). Ibadan: Hope Publications.

Okere, T. (1996). The structure of the self in Igbo thought. In T. Okere (Ed.), Identity and Change (pp. 151-162). Washington DC: The Council for Research in Values and Philosophy.

Okolo, B. C. (1987). What is African philosophy (pp. 31,37,61). Enugu: Freeman's Press.

Okolo, B. C. (1992a). African philosophy: An overview (pp. 30,50,64). Enugu: CECTA Publications.

Okolo, B. C. (1992b). Philosophy and Nigerian politics (pp. 17-29). Enugu: CECTA Publication.

Okonkwo, P. (2005). Traditionalism and Christianity comprises or dialogue. African Philosophy and of Godhood and Traditionalism, 2, 115-131.

Olusanya, G. et al. (1998). Economic development and foreign policies in Nigeria (p. 9). Lagos: Hope Publication.

Ome, E. (2007). Philosophy, democracy and African development; the relevance of Nyerere's political philosophy. In I. Odimegwu et al., Philosophy, democracy and conflicts in Africa (Vol. 2, p. 141). Awka: ATAB Educational Book.

Omoregbe, J. I. (2007). Knowing philosophy (2nd ed., pp. 1,197). Lagos: Joga Press.

Oxford Dictionary of Politics (1996). USA: Oxford University Press.
Ozumba, G. O. (2003). A colloquium on African philosophy (Vol. 1, p. 1). Calabar: Pyramid publication.

Paradigm: Research Paradigm. URL (last checked 4 September 2012). http://www.personal.psu.edu/wxh/39/paradigm

Popkin, R. H. et al. (1993). Philosophy made simple (p. 101). New York: Doubleday Publications.

Research and Paradigms. URL (last checked 4 September 2012). http://www.umdnji.edu/edsweb/idst600/willians-research+paradigms. htm

Richard, B. H. (2002). Understanding African philosophy: A crosscultural approach to classical and contemporary issues (p. 61). New York: Routledge.

Rodney, W. (1990). How Europe underdeveloped Africa (p. 9). London: Boglelouvertrue Publication.

Ruch, A. E., \& Anyanwu, K. C. (1981). Africa philosophical trend in contemporary Africa (p. 168). Rome: Catholic Book Agency.

Russell, B. (1934). Freedom and organization: 1814-1914 (p. 453). London: Allen and Union.

Steven, E. K. (2005). Research paradigm and meaning making: A primer. Qualitative Report, 10, 2005. http://www.nova.edu/ssss/QR/

Temples, P. (1959). Bantu philosophy (pp. 60,103). Paris: Presence Africaine.

Toyin, F. (2000). British and Nigeria: Exploitation or development in Africa (p. 16). Ibadan: Fourth Dimension Publication.

Uroh, C. (1998). Africa and the challenges of development: Essays by Samir Amin (p. 2). Ibadan: Hope Publications.

Webster's Universal Dictionary and Thesaurus (2007). New York: Geddes and Grosset Press.

Wikipedia, the Free Encyclopedia (2012). New partnership for Africa's development. URL (last checked 5 September 2012). http://en.wikipedia.org/wiki/NEPAD

Wikipedia, the Free Encyclopedia (2012). Paradigm. URL (last checked 4 September 2012). http://www.paradigm 